\title{
Analysis of the productivity of the distribution process of the company DICONSA in Villahermosa Tabasco, for the generation of a proposal for improvement
}

\section{Análisis de la productividad del proceso de distribución de la empresa DICONSA en Villahermosa Tabasco, para la generación de una propuesta de mejora}

\author{
MARTÍNEZ-GUTIÉRREZ, Ana Cecilia†*, LOPEZ-VALDIVIESO, Leticia, TORRES-TORRES, Adán \\ and ELISEO-DANTÉS, Hortensia
}

Tecnológico Nacional de México/ Instituto Tecnológico de Villahermosa

ID $1^{\text {st }}$ Author: Ana Cecilia, Martínez-Gutiérrez / ORC ID: 0000-0003-1767-4776, PubMed ID: 572aea33007c334e1833538746c6f90bcb08, CVU CONACYT ID: 919669

ID $1^{\text {st }}$ Coauthor: Leticia, López-Valdivieso / ORC ID: 0000-0001-6288-3636 - Researcher ID Thomson ID: G-5753-2018 CVU CONACYT: 67839

ID $2^{\text {nd }}$ Coauthor: Adan, Torres-Torres / ORC ID: 0000-002-1017-5694 - CVU CONACYT: 914347

ID $3^{\text {rd }}$ Coauthor: Hortensia, Eliseo- Dantés / ORC ID: 0000-0003-4006-4669, Researcher ID Thomson: F-6749, - PubMed Autor ID: 6eb3adfd69824484b018f668c2670f109f08 - CVU CONACYT ID: 411079

\section{Abstract}

The objective is to carry out an analysis of the productivity of the distribution process, in the company DICONSA in Villahermosa Tabasco, for the generation of a proposal for improvement. This research will address topics of interest on the productivity of the distribution process, of the company DICONSA that is responsible for supporting both urban and rural communities. Productivity is a topic of great interest within the business sector, since based on it; The future of any company depends on the application and its use within the organization. Productivity indicators are essential to really know what state an organization is in. The research method is descriptive, since it was made from documentary research of primary and secondary sources of information. It will contribute with a diagnosis of the situation of the company and a model of improvement for productivity, within the company DICONSA located in Villahermosa, Tabasco.

Productivity, improvement, processes

\section{Resumen}

El objetivo es realizar un análisis de la productividad del proceso de distribución, en la empresa DICONSA en Villahermosa Tabasco, para la generación de una propuesta de mejora. En la presente investigación se abordarán temas de interés sobre la productividad del proceso de distribución, de la empresa DICONSA que se encarga de apoyar a las comunidades tanto urbanas como rurales. La productividad es un tema de gran interés dentro del sector empresarial, ya que en base a esta; el futuro de cualquier empresa depende de la aplicación y el uso que se le dé dentro de la organización. Los indicadores de productividad son totalmente imprescindibles para saber realmente en qué estado se encuentra una organización. El método de investigación es descriptivo, ya que se realizó a partir de investigación documental de fuentes primarias y secundarias de información. Se contribuirá con un diagnóstico de la situación de la empresa y un modelo de mejora para la productividad, dentro de la empresa DICONSA ubicada en Villahermosa, Tabasco.

Productividad, mejora, procesos

Citation: MARTÍNEZ-GUTIÉRREZ, Ana Cecilia, LOPEZ-VALDIVIESO, Leticia, TORRES-TORRES, Adán and ELISEO-DANTÉS, Hortensia. Analysis of the productivity of the distribution process of the company DICONSA in Villahermosa Tabasco, for the generation of a proposal for improvement. RINOE Journal- Macroeconomics and monetary economy. 2019. 3-4: 20-23.

\footnotetext{
* Correspondence to Author (email: ana.c.mtz.91@gmail.com)

$\uparrow$ Researcher contributing first author.
} 


\section{Introduction}

The present project presented below stems from the interest of seeking an answer to the problem that is being presented in the company DICONSA is called "analysis of productivity in the company DICONSA in Villahermosa, Tabasco, for the generation of a proposal for improvement. Productivity is a topic of great interest within the business sector, since based on it; The future of any company depends on the application and use that is given within the organization. The fundamental characteristic is in the Quality, so that the achievement of quality in all companies is not the product of a Quality Program or System, but is the development of a strategy aimed at the continuous improvement of this, throughout the company.

The main importance of this is not only the market in general, but the knowledge of the needs and expectations of customers, to build a business organization that meets them. Productivity indicators are absolutely essential to really know what state an organization is in. These indicators are made up of those variables that help us identify the defects or imperfections that exist when we produce a product or offer a service to our potential customers. In this way, we can see the efficiency of general and human resources reflected. These indicators can be of two types: quantitative and qualitative.

Productivity can be broken down into several indices. As for materials, you can see how much material is bought, and when it goes on sale, and with that see the waste or how much material is wasted, and study how to take advantage of it. This would be the productivity of the raw material used.

Currently in the company problems have been generated in terms of employee productivity, which has been causing discomfort and discomfort in the work environment. Employers try to know what are the basic reasons for these problems and workers also raise the reasons, which is why it is important to know and evaluate the main factors that are influencing the productivity of DICONSA. Explanation of the sections of the Article

\section{Development of Sections and Sections of the Article with subsequent numbering}

It is intended to conduct a questionnaire with which you can perform an analysis of the processes and thus obtain results that help us to perform an analysis. By June 2020 it is intended to have an analysis of the processes and procedures within the company DICONSA located in the city of Villahermosa, Tabasco.

- A diagnosis of the company's situation.

- A model of improvement for the productivity of the distribution process, within the company DICONSA located in Villahermosa, Tabasco.

\section{Hypothesis}

The variables that are involved in this problem are economic, social, cultural, political, environmental and technological, these influence the productivity of the company DICONSA in Villahermosa, Tabasco.

\section{Kind of investigation}

\section{Documentary}

It is characterized by the selection and collection of information with documents that can be of various types: printed, electronic; Information is also collected through reading and bibliographic material.

\section{Correlationals}

Since some variables that incur research are mentioned, they must be correlated so that they can be studied. They should be editable and with numbering aligned on the far right.

\section{Methodology to be developed}

Productivity began to be present from the time of classical economists such as Adam Smith (1776) and David Ricardo (1817), who emphasized producing at low costs and the differences between the production conditions of the countries and in the differentiated position of production factors, this theorist considered international trade always beneficial for the country that had production costs were lower than the other country with which it is traded. 
On the other hand, in more recent times we have Bordas (1993). For this author, productivity is the ability to achieve their objectives, in a manner superior to the average of the reference sector and in a sustainable way, that is; ability to obtain returns on investments above average, reasonably and ability to do so with low social and environmental costs.

Esser (1994) also indicates that productivity does not arise spontaneously when the macro context is modified nor is it created exclusively using the spirit of enterprise at the micro level. It is rather the product of a pattern, of complex and dynamic interaction between the state, companies, institutions, intermediaries and the organizational capacity of a society.

In this modern context, Michael Porter, an academic at Harvard University, also emerges with his book The Competitive Advantage of Nations. For Porter, productivity is determined by the productivity with which a nation, region or cluster uses natural, human, and capital resources. Productivity sets the standard of living of a nation or region (wages, returns to capital, returns to natural resources endowments).

So productivity refers to the ability of a company or country to obtain profitability in the market in relation to its competitors and the ability to create added value.

\section{How to improve productivity}

For (Larkin., 2019), productivity management depends on identifying people as the key to productivity. consider remuneration as the foundation - although not the entire productivity management building, workers must warn that their pay is adequate, but achieved this, the remuneration loses its motivating effectiveness and non-monetary considerations become more important.

\section{Problem delimitation}

The problem to solve will be based mainly on analyzing the productivity of the distribution process in the company DICONSA in Villahermosa, Tabasco; for this it is tried to elaborate a diagnosis of the productivity and generate a model of improvement; with a two year period from December 2018 to March 2020.

\section{The specific objectives of this project are}

- Develop a diagnosis of productivity that exists in the diconsa company.

- Develop a productivity improvement plan in the aspects needed by the company.

- Analyze all the benefits that will be obtained with the implementation of the improvement proposal.

\section{Productivity Index}

The numerical value of this relationship between production obtained and resources used is known as the Productivity Index. Production: total products produced.

$$
\begin{aligned}
& \text { Resources: Labor, raw material, } \\
& \text { machinery, energy, capital. }
\end{aligned}
$$

As you can see, the productivity index is nothing more than the numerical value with which productivity is designated or denominated, it is evident that the situation of the object under analysis will be better, the higher the productivity index, which will be achieved by any of the following paths, products of a simple mathematical analysis of such relationship:

\section{Increase production by keeping resources constant.}

Reduce resources by keeping production constant.

Increase production in a proportion that is greater than the coefficient of growth of resources. As you can see, the productivity index is nothing more than the numerical value with which productivity is designated or denominated, it is evident that the situation of the object under analysis will be better, the higher the productivity index, which will be achieved by any of the following paths, products of a simple mathematical analysis of such relationship:

Increase production by keeping
resources constant.

Reduce resources by keeping production constant. 
Increase production in a proportion that is greater than the coefficient of growth of resources.

\section{References}

C.V, D. S. (07 de 2009). Obtenido de https://www.google.com.mx/search-

productividad+en+las+empresas+de+tiendas $+c$ omunitarias

F, D. (2017). Ingenieria de metodos. En D. F, Analsis de operaciones (pág. 357). McGraw-Hill Education.

Larkin., F. E. (01 de 09 de 2019). eumed. Obtenido de http://www.eumed.net/librosgratis/2005/dfch-fun/F31.2.htm

Rodriguez José, C. J. (2007). Productividad Organizacional. En R. Jose. Venezuela. 